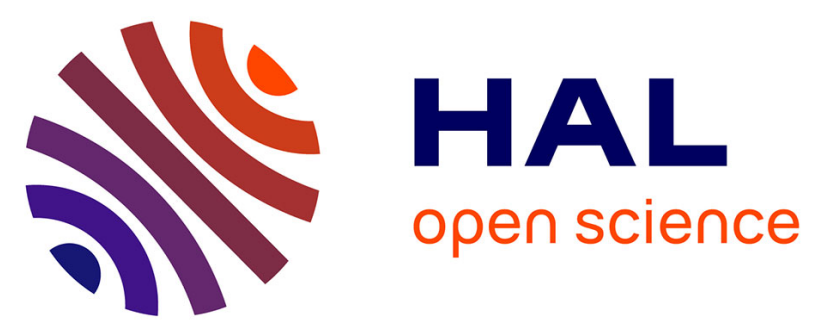

\title{
Nanopatterned front contact for broadband absorption in ultra-thin amorphous silicon solar cells
}

I. Massiot, Clément Colin, Nicolas Péré-Laperne, Pere Roca I Cabarrocas, Christophe Sauvan, Philippe Lalanne, Jean-Luc Pelouard, Stéphane Collin

\section{- To cite this version:}

I. Massiot, Clément Colin, Nicolas Péré-Laperne, Pere Roca I Cabarrocas, Christophe Sauvan, et al.. Nanopatterned front contact for broadband absorption in ultra-thin amorphous silicon solar cells. Applied Physics Letters, 2012, 101 (16), pp.163901. 10.1063/1.4758468 hal-00812771

HAL Id: hal-00812771

https://hal-iogs.archives-ouvertes.fr/hal-00812771

Submitted on 16 Nov 2015

HAL is a multi-disciplinary open access archive for the deposit and dissemination of scientific research documents, whether they are published or not. The documents may come from teaching and research institutions in France or abroad, or from public or private research centers.
L'archive ouverte pluridisciplinaire HAL, est destinée au dépôt et à la diffusion de documents scientifiques de niveau recherche, publiés ou non, émanant des établissements d'enseignement et de recherche français ou étrangers, des laboratoires publics ou privés. 


\section{AIP Aponed phosics \\ Letters}

\section{Nanopatterned front contact for broadband absorption in ultra-thin amorphous silicon solar cells}

Inès Massiot, Clément Colin, Nicolas Péré-Laperne, Pere Roca i Cabarrocas, Christophe Sauvan, Philippe Lalanne, Jean-Luc Pelouard, and Stéphane Collin

Citation: Applied Physics Letters 101, 163901 (2012); doi: 10.1063/1.4758468

View online: http://dx.doi.org/10.1063/1.4758468

View Table of Contents: http://scitation.aip.org/content/aip/journal/apl/101/16?ver=pdfcov

Published by the AIP Publishing

\section{Articles you may be interested in}

Hybrid $\mathrm{ZnO}$ nanowire/a-Si: $\mathrm{H}$ thin-film radial junction solar cells using nanoparticle front contacts

Appl. Phys. Lett. 107, 143903 (2015); 10.1063/1.4932649

Plasmonic excitation-assisted optical and electric enhancement in ultra-thin solar cells: the influence of nano-strip cross section

AIP Advances 5, 087126 (2015); 10.1063/1.4928517

Highly efficient ultrathin-film amorphous silicon solar cells on top of imprinted periodic nanodot arrays Appl. Phys. Lett. 106, 093902 (2015); 10.1063/1.4914110

Multi-resonant silver nano-disk patterned thin film hydrogenated amorphous silicon solar cells for StaeblerWronski effect compensation

J. Appl. Phys. 116, 093103 (2014); 10.1063/1.4895099

Optimal design of one-dimensional photonic crystal back reflectors for thin-film silicon solar cells

J. Appl. Phys. 116, 064508 (2014); 10.1063/1.4893180

\section{AIP $\mid$ APL Photonics}

APL Photonics is pleased to announce Benjamin Eggleton as its Editor-in-Chief

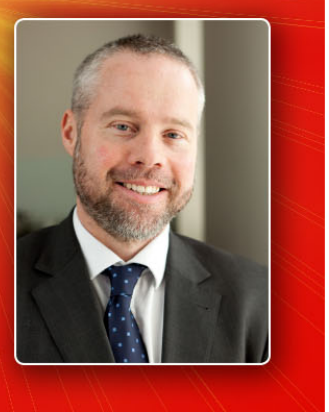




\title{
Nanopatterned front contact for broadband absorption in ultra-thin amorphous silicon solar cells
}

\author{
Inès Massiot, ${ }^{1}$ Clément Colin, ${ }^{1,2}$ Nicolas Péré-Laperne, ${ }^{1, a)}$ Pere Roca i Cabarrocas, ${ }^{3}$ \\ Christophe Sauvan, ${ }^{4}$ Philippe Lalanne,${ }^{4}$ Jean-Luc Pelouard, ${ }^{1}$ and Stéphane Collin ${ }^{1, b)}$ \\ ${ }^{1}$ Laboratoire de Photonique et de Nanostructures (LPN-CNRS), Route de Nozay, 91460 Marcoussis, France \\ ${ }^{2}$ Institut de Recherche et Développement sur l'Energie Photovoltaïque (IRDEP-UMR 7174 \\ CNRS/EDF/Chimie-ParisTech), 6 quai Watier, 78401 Chatou, France \\ ${ }^{3}$ Laboratoire de Physique des Interfaces et Couches Minces (LPICM-CNRS), Ecole Polytechnique, \\ 91128 Palaiseau Cedex, France \\ ${ }^{4}$ Laboratoire Photonique, Numérique et Nanosciences (LP2N), Université Bordeaux 1/CNRS/ \\ Institut d'Optique, 33405 Talence Cedex, France
}

(Received 25 June 2012; accepted 25 September 2012; published online 15 October 2012)

\begin{abstract}
Broadband light trapping is numerically demonstrated in ultra-thin solar cells composed of a flat amorphous silicon absorber layer deposited on a silver mirror. A one-dimensional silver array is used to enhance light absorption in the visible spectral range with low polarization and angle dependencies. In addition, the metallic nanowires play the role of transparent electrodes. We predict a short-circuit current density of $14.6 \mathrm{~mA} / \mathrm{cm}^{2}$ for a solar cell with a $90 \mathrm{~nm}$-thick amorphous silicon absorber layer. @ 2012 American Institute of Physics. [http://dx.doi.org/10.1063/1.4758468]
\end{abstract}

Thin film solar cells based on amorphous silicon are a promising solution to achieve low-cost and efficient photovoltaic devices. ${ }^{1}$ This technology has many advantages as it uses an abundant and non-toxic material which can be deposited at low temperature and on large areas. The latest record of $10 \%$ efficiency for an hydrogenated amorphous silicon (a-Si:H) solar cell was achieved in 2009 with a $250 \mathrm{~nm}$-thick active layer. ${ }^{2}$ Reducing further the thickness of the absorbing layer could lead to higher open-circuit voltages ${ }^{3}$ and thereby boost the solar cell conversion efficiency. In addition, for a-Si:H, the use of a thinner active layer increases the stability of the cell under light soaking. ${ }^{4,5}$ Achieving efficient light absorption within ultra-thin active layers (thickness $\leq 100 \mathrm{~nm}$ ) requires advanced concepts of light management; losses in contact layers must also be reduced. Due to their ability to confine light in small volumes, plasmonic nanostructures have been proposed to enhance light absorption in photovoltaic devices. ${ }^{6-10}$ It has been shown that sinusoidal gratings ${ }^{11}$ and twodimensional nanoparticles ${ }^{12-14}$ patterned on the back contact allow the incident light to couple with guided modes supported by the a-Si:H layer. Yet, the growth of amorphous silicon on textured substrates results in a higher defect density as demonstrated by Söderström ${ }^{15}$ and Python. ${ }^{16}$

In this paper, we propose a design for broadband light trapping in ultra-thin amorphous silicon solar cells using a one-dimensional (1D) silver array embedded in the front layer of the cell. We demonstrate numerically that, despite the polarization selectivity of the structure, broadband absorption is achieved in the flat absorbing layer with low polarization and angle dependencies. We analyze the physical mechanism behind the absorption enhancement in the red part of the solar spectrum $(\lambda>600 \mathrm{~nm})$. In addition, the metallic nanowires play the role of transparent conductive electrodes. This results in a short-circuit current density $\left(J_{s c}\right)$ of $14.6 \mathrm{~mA} / \mathrm{cm}^{2}$ with a $90 \mathrm{~nm}$-thick a-Si:H absorber layer.

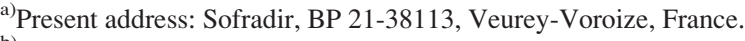

${ }^{\mathrm{b})}$ E-mail address: stephane.collin@1pn.cnrs.fr.
}

The optical properties of the structures are simulated with fully vectorial numerical calculations obtained with a rigorous coupled-wave analysis method. ${ }^{17,18}$ For TM polarization (magnetic field parallel to the wires), the field calculation in the cell is performed with a semi-analytical treatment ${ }^{19}$ for the sake of accuracy. The metallic parts (back contact and grating) are made of silver. Optical constants of silver (Ag) and silicon nitride $\left(\mathrm{Si}_{3} \mathrm{~N}_{4}\right)$ are taken from Ref. 20 and Ref. 21 respectively. The refractive indices of a-Si:H, indium tin oxide (ITO), and aluminum doped zinc oxide ( $\mathrm{ZnO}: \mathrm{Al})$ were measured by ellipsometry.

We first consider a reference structure corresponding to a conventional a-Si:H solar cell deposited on a silver mirror: Ag/ZnO:Al $(15 \mathrm{~nm}) / \mathrm{a}-\mathrm{Si}: \mathrm{H}(90 \mathrm{~nm}) / \mathrm{ITO}(70 \mathrm{~nm})$. We use numerical simulations to design the thicknesses of the stack in order to maximize the integrated absorption at normal incidence, while keeping an absorber layer thinner than $100 \mathrm{~nm}$. The absorption spectrum of this reference structure is shown in Fig. 1 (dashed curve). The spectral photon flux density corresponding to the normalized AM1.5 G solar spectrum $\Phi_{1.5}(\lambda)$ is shown as a reference (grey curve). The reference cell exhibits an absorption maximum in the $450-550 \mathrm{~nm}$ wavelength range because of a broad Fabry-Perot-like resonance in the multilayer stack. However, the absorption efficiency drops in the red part of the solar spectrum $(\lambda>600 \mathrm{~nm})$. In addition, the use of ITO as a front contact layer results in poor a-Si:H absorption at short wavelengths. Our objective is to show that the performance of this optimized structure can be further enhanced by an alternative front contact made of metal nanowire electrodes.

The optimization of transparent conductive electrodes using metallic films as an alternative to ITO front layers has been investigated in recent theoretical ${ }^{22}$ and experimental ${ }^{23-25}$ works. In Ref. 23, two-dimensional networks of silver nanowires patterned on glass are shown to exhibit lower sheet resistance and larger optical transmittance than those achieved with $80 \mathrm{~nm}$-thick ITO layers. Therefore, we propose to replace the ITO layer by a thin 1D metallic grating 


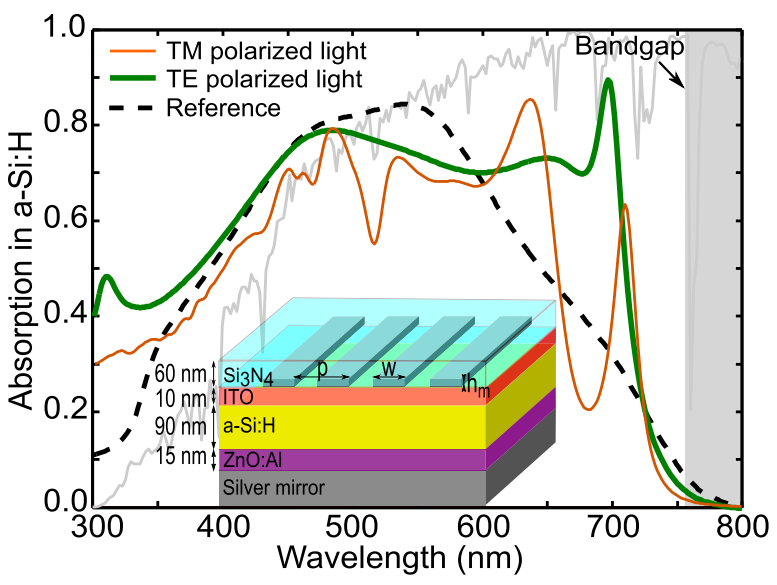

FIG. 1. Theoretical absorption in the a-Si:H layer of the ultra-thin solar cell depicted in the inset under TE (green) and TM (orange) polarizations at normal incidence. The structure investigated has a $90 \mathrm{~nm}$-thick a-Si:H absorber layer. The grating parameters are $h_{m}=20 \mathrm{~nm}, w=80 \mathrm{~nm}$, and $p=200 \mathrm{~nm}$. The normalized AM1.5 G solar spectrum is shown as a reference (grey curve). Dashed curve: absorption spectrum of the reference structure (same thickness, ITO front layer (70 nm), no grating).

embedded in a transparent anti-reflection coating layer, so that the collection of current relies only on the metallic nanowires. The sheet resistance $R_{s}$ of a silver 1D mesh is given by $R_{s}=\rho p / w h_{m}$, where $\rho=1.59 \cdot 10^{-8} \Omega \cdot \mathrm{m}$ is the bulk resistivity of $\mathrm{Ag}, p$ is the grating period, $w$ the width of the wires, and $h_{m}=20 \mathrm{~nm}$ is the metal thickness. In our case, in the direction parallel to the wires, we obtain estimated values of $R_{s}$ between $0.8 \Omega /$ sq for a non-patterned metallic film to 8 . $\Omega /$ sq for $w / p=0.1$ (Ref. 22) (to be compared with $R_{s} \sim$ $60 \Omega$ /sq for the reference structure with a top ITO layer ${ }^{23}$ ).

The ultra-thin a-Si:H solar cell considered in the following is displayed in Fig. 1 (inset). The 1D silver grating is covered by a $60 \mathrm{~nm}$-thick $\mathrm{Si}_{3} \mathrm{~N}_{4}$ layer. We have added two spacing layers above (ITO, $10 \mathrm{~nm}$ ) and below ( $\mathrm{ZnO}: \mathrm{Al}$, $15 \mathrm{~nm}$ ) the a-Si:H layer to prevent diffusion of the metal. Light transmission is avoided by the use of a silver mirror as back contact. Figure 1 displays the absorption spectra resulting from this optimization procedure, with the same a-Si:H layer thickness as the reference structure $\left(h_{s}=90 \mathrm{~nm}\right)$. The parameters of the optimized grating are $h_{m}=20 \mathrm{~nm}$, $w=80 \mathrm{~nm}$, and $p=200 \mathrm{~nm}$. The absorption intensity in the a-Si:H absorber layer is calculated for both TM (magnetic field parallel to the wires) and TE (electric field parallel to the wires) light polarizations at normal incidence.

Introducing the metallic grating in the top $\mathrm{Si}_{3} \mathrm{~N}_{4}$ layer enables a significant absorption enhancement up to $720 \mathrm{~nm}$. The optical absorption is enhanced at short wavelengths ( $\lambda \leq 400 \mathrm{~nm}$ ) with respect to the reference cell. This is due to reduced absorption losses in the front contact. Multiresonant absorption spectra are observed between 400 and $700 \mathrm{~nm}$. Indeed, in the red part of the spectrum, light trapping effects are achieved very close to the electronic bandgap of amorphous silicon $\left(\lambda_{g}=760 \mathrm{~nm}\right)$, with resonance wavelengths at $\lambda \simeq 700 \mathrm{~nm}$ for both TE and TM polarizations. Due to the anisotropy of the $1 \mathrm{D}$ grating, the positions and intensities of the absorption peaks corresponding to the different resonances in the structure vary with the polarization of incident light. The period of the grating has been identified as the main geometrical parameter for the optimization of these resonance wavelengths. The periodicity dependence is illustrated in Fig. 2, for (a) TM and (b) TE polarizations. The spectral shift can be attributed to the excitation of guided modes in the multilayer structure via grating coupling. ${ }^{11,13,26,27}$ The electric field intensity is plotted in Fig. 2(c) for each resonance wavelength. In TM polarization, the plasmonic nature of the guided modes is identified through the field enhancement close to the metal. In TE polarization, the guided mode is mainly confined in the a$\mathrm{Si}: H$ layer, leading to slightly lower metal absorption.

The absorption spectrum $A(\lambda)$ within the a-Si:H active layer is used to predict the performances of the solar cell. The theoretical short-circuit current density $J_{S C}$ is calculated for AM1.5 G solar illumination with the expression

$$
J_{S C}=q \int \frac{A(\lambda) \Phi_{1.5}(\lambda) \lambda}{h c} d \lambda,
$$

assuming that all generated carriers are collected. In Eq. (1), $q$ is the electron charge, $h$ is the Planck constant, and $c$ is the light speed. A short-circuit current density of $14.6 \mathrm{~mA} / \mathrm{cm}^{2}$ is obtained for a $90 \mathrm{~nm}$-thick a-Si:H absorber layer at normal incidence, which represents a gain of $0.6 \mathrm{~mA} / \mathrm{cm}^{2}$ with respect to the reference cell. A theoretical conversion efficiency of $9 \%$ is predicted using state-of-the-art values for the electrical characteristics of the device (open-circuit voltage $\mathrm{V}_{\mathrm{OC}}=0.88 \mathrm{~V}$ and fill factor $\mathrm{FF}=0.7$ (Ref. 11)). We also investigate the dependence of $J_{S C}$ with the angle of incidence $\theta$ of the impinging photons (plane of incidence perpendicular to the nanowires) for an unpolarized incident light. We find that the short-circuit current density of the optimized structure weakly depends on the angle of incidence and the polarization of the incident light (see the inset of Fig. 3). For $\theta=70^{\circ}$, the $J_{s c}$ value still represents more than $80 \%$ of the short-circuit current density at normal incidence.

We expect several beneficial effects of the present architecture on the electrical properties of the cell with respect to conventional amorphous silicon solar cells. First, the use of a thin $\mathrm{p}-\mathrm{i}-\mathrm{n}$ junction should provide a better stability of the cell
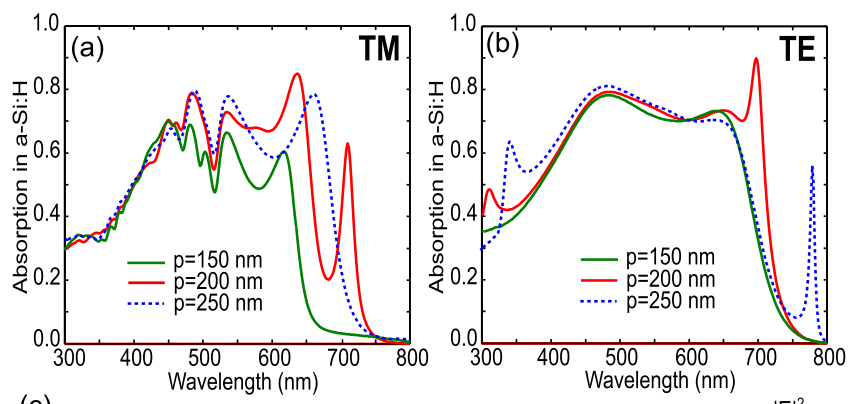

(c)
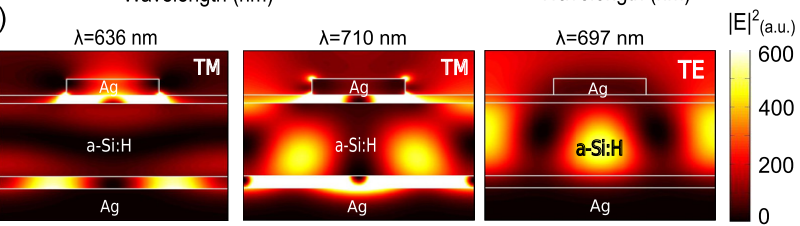

FIG. 2. Evolution of the absorption intensity in the a-Si:H layer as a function of the grating period $p$ under (a) TM and (b) TE polarizations. The other parameters of the structure are $h_{s}=90 \mathrm{~nm}, h_{m}=20 \mathrm{~nm}, w=80 \mathrm{~nm}$. (c) Electric field intensity maps for an excitation at $\lambda=636 \mathrm{~nm}$ (TM), $\lambda=710 \mathrm{~nm}$ (TM), and $\lambda=697 \mathrm{~nm}$ (TE) at normal incidence for a structure with $p=200 \mathrm{~nm}$. 


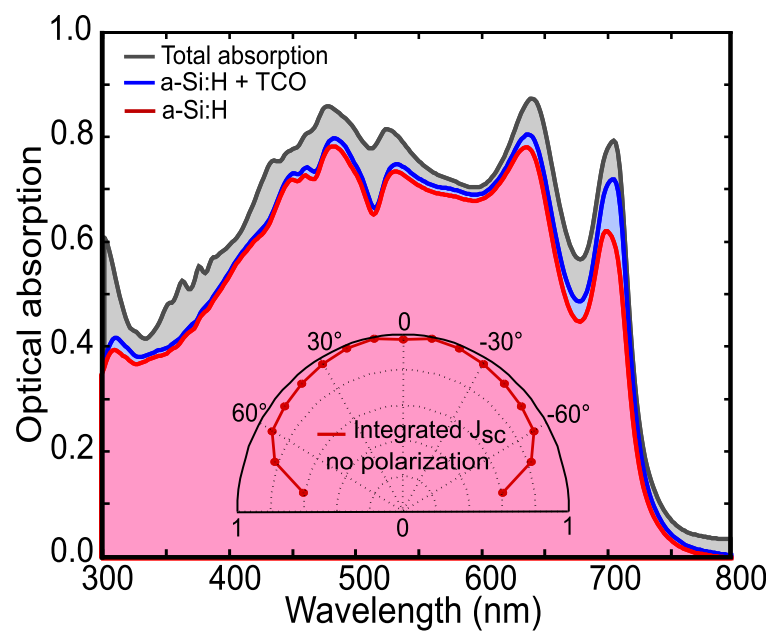

FIG. 3. Calculated absorption in each material of the structure described in Fig. 1 for an excitation under unpolarized light at normal incidence. Inset: Angular dependence of the integrated short-circuit current density. The values of $J_{S C}$ are normalized with respect to the value at normal incidence (equal to $14.6 \mathrm{~mA} / \mathrm{cm}^{2}$ ).

against light-induced degradation. Due to the StaeblerWronski effect, ${ }^{4}$ defects are created in the bandgap during light soaking thereby degrading the photoconductivity of a-Si:H. Decreasing the intrinsic layer thickness allows to maintain an effective carrier collection in spite of the additional recombination centers. ${ }^{5}$

Second, a thinner $\mathrm{p}-\mathrm{i}-\mathrm{n}$ junction exhibits a decrease of bulk recombinations and thus of the dark current $\mathrm{I}_{\text {dark }}$. It thereby should lead to an increase of the open-circuit voltage as $\mathrm{V}_{\mathrm{OC}}=\mathrm{n} \frac{\mathrm{kT}}{\mathrm{q}} \ln \left(\frac{\mathrm{I}_{\text {photo }}}{\mathrm{I}_{0}}+1\right)$, where $\mathrm{k}$ is the Boltzmann constant, $\mathrm{T}$ is the temperature, and $\mathrm{n}$ is the ideality factor of the diode. $\mathrm{I}_{\text {photo }}$ and $\mathrm{I}_{0}$ are the photogenerated and saturation currents, respectively, and $\mathrm{I}_{\text {dark }}=\mathrm{I}_{0}\left(\mathrm{e}^{\mathrm{qV} / \mathrm{kT}}-1\right)$.

Third, as previously mentioned, it has been shown that the growth of amorphous silicon on a textured substrate leads to the formation of voids and cracks in the $n$ doped layer. ${ }^{15,16}$ These low density and porous regions favor carrier recombination and form contamination routes for doping atoms and impurities. In our design, we manage strong light trapping within the solar cell while preserving a flat amorphous silicon layer. Thus, we avoid detrimental consequences on the electrical performances (low fill factor and open circuit voltage).

As the plasmonic structures are deposited on top of the active layer, we expect significant absorption losses in the metal, especially at short wavelengths. In the calculations, we separately consider the absorption fractions in the different materials of the stack. The resulting absorption spectra are shown in Fig. 3. It is noteworthy that only $6 \%$ (on average between 300 and $800 \mathrm{~nm}$ ) of the incident photons are absorbed within the metal. This is due to the thin metallic grating used in this structure $\left(h_{m}=20 \mathrm{~nm}\right)$ and to the high refractive index and absorption coefficient of amorphous silicon.

In summary, we have shown that the introduction of a thin 1D metallic grating in the front window of an ultra-thin solar cell enables an absorption enhancement over the whole solar spectrum. Unexpectedly, we have demonstrated numerically that the optical response of the cell was almost insensitive to the light polarization despite the use of an anisotropic grating. In this design, the metallic nanowires are also used for the collection of current in the front contact. The conventional ITO front window is thereby replaced by a non-absorbing material $\left(\mathrm{Si}_{3} \mathrm{~N}_{4}\right)$ in order to decrease optical and electrical losses. This results in a theoretical short-circuit current density of $14.6 \mathrm{~mA} / \mathrm{cm}^{2}$ for a $90 \mathrm{~nm}$-thick a-Si:H absorber layer.

This multi-resonant approach can be used to enhance absorption in high-efficient devices such as tandem amorphous/microcrystalline silicon solar cells. It additionally offers an alternative to the use of an intermediate reflector to match the currents of the two junctions. The realization of solar cells using nanopatterned metallic gratings in the front window may open the way towards a new generation of efficient and low-cost ultra-thin solar cells.

The authors would like to thank J. F. Guillemoles and A. Cattoni for fruitful discussions. This work was partially supported by the ANR project ULTRACIS.

${ }^{1}$ A. V. Shah, H. Schade, M. Vanecek, J. Meier, E. Vallat-Sauvain, N. Wyrsch, U. Kroll, C. Droz, and J. Bailat, Prog. Photovoltaics 12, 113-142 (2004).

${ }^{2}$ S. Benagli, D. Borrello, E. Vallat-Sauvain, J. Meier, U. Kroll, J. Hötzel, J. Spitznagel, J. Steinhauser, L. Castens, and Y. Djeridane, in Proceedings of the 24th European Photovoltaic Solar Energy Conference, Hamburg, September 2009, pp. 2293-2298.

${ }^{3}$ P. Campbell and M. A. Green, IEEE Trans. Electron Devices 33(2), 234-239 (1986).

${ }^{4}$ D. L. Staebler and C. R. Wronski, J. Appl. Phys. 51(6), 3262-3268 (1980).

${ }^{5}$ B. Rech and H. Wagner, Appl. Phys. A 69, 155-167 (1999).

${ }^{6}$ H. A. Atwater and A. Polman, Nature Mater. 9(3), 205-213 (2010).

${ }^{7}$ M. A. Green and S. Pillai, Nature Photon. 6, 130-132 (2012).

${ }^{8}$ V. E. Ferry, J. N. Munday, and H. A. Atwater, Adv. Mater. 22, 4794-4808 (2010).

${ }^{9}$ A. Cattoni, P. Ghenuche, A. M. Haghiri-Gosnet, D. Decanini, J. Chen, J. L. Pelouard, and S. Collin, Nano Lett. 11, 3557 (2011).

${ }^{10}$ K. Aydin, V. E. Ferry, R. M. Briggs, and H. A. Atwater, Nat. Commun. 2, 517 (2011).

${ }^{11}$ K. Söderström, F. J. Haug, J. Escarre, O. Cubero, and C. Ballif, Appl. Phys. Lett. 96, 213508 (2010).

${ }^{12}$ J. Zhu, C. M. Hsu, Z. Yu, S. Fan, and Y. Cui, Nano. Lett. 10, 1979-1984 (2010).

${ }^{13}$ V. E. Ferry, M. A. Verschuuren, H. B. T. Li, E. Verhagen, R. J. Walters, R. E. I. Schropp, H. A. Atwater, and A. Polman, Opt. Express 18, A237A245 (2010).

${ }^{14}$ V. E. Ferry, M. A. Verschuuren, C. van Lare, R. E. I. Schropp, H. A. Atwater, and A. Polman, Nano Lett. 11(10), 4239-4245 (2011).

${ }^{15}$ T. Söderström, F. J. Haug, V. Terrazoni-Daudrix, and C. Ballif, J. Appl. Phys. 103, 114509 (2008).

${ }^{16}$ M. Python, O. Madani, D. Dominé, F. Meillaud, E. Vallat-Sauvain, and C. Ballif, Sol. Energy Mater. Sol. Cells 93, 1714-1720 (2009).

${ }^{17}$ M. G. Moharam, E. B. Grann, D. A. Pommet, and T. K. Gaylord, J. Opt. Soc. Am. A 12, 1068-1076 (1995).

${ }^{18}$ P. Lalanne and G. M. Morris, J. Opt. Soc. Am. A 13, 779-789 (1996).

${ }^{19}$ P. Lalanne and M. P. Jurek, J. Mod. Opt. 45, 1357-1374 (1998).

${ }^{20}$ P. B. Johnson and R. W. Christy, Phys. Rev. B 6, 4370-4379 (1972).

${ }^{21}$ E. Palik, Handbook of Optical Constants of Solids, 1 st edition (Academic Press, Orlando, 1985).

${ }^{22}$ P. B. Catrysse and S. Fan, Nano Lett. 10, 2944-2949 (2010).

${ }^{23}$ J. van de Groep, P. Spinelli, and A. Polman, Nano Lett. 12, 3138-3144 (2012).

${ }^{24}$ I. Crupi, S. Boscarino, V. Strano, S. Mirabella, F. Simone, and A. Terrasi, Thin Solid Films 520, 4432-4435 (2012).

${ }^{25}$ P. Kuang, J.-M. Park, W. Leung, R. C. Mahadevapuram, K. S. Nalwa, T.-G. Kim, S. Chaudhary, K.-M. Ho, and K. Constant, Adv. Mater. 23, 2469-2473 (2011).

${ }^{26}$ F. J. Haug, T. Söderström, O. Cubero, V. Terrazoni-Daudrix, and C. Ballif, J. Appl. Phys. 106, 044502 (2009).

${ }^{27}$ V. E. Ferry, L. A. Sweatlock, D. Pacifici, and H. A. Atwater, Nano Lett. 8(12), 4391-4397 (2008). 